\title{
Bozçay Havzası Su Kalitesi Özelliklerinin Belirlenmesi ve Çevresel Baskılar Açısından Değerlendirilmesi
}

\author{
Selma AYAZ ${ }^{* 1}$, Nail ERDOĞAN² \\ 1,2TUBITAK Marmara Research Center, Environment and Cleaner Production Institute, 414470, Kocaeli, Türkiye
}

(Alınış / Received: 19.03.2021, Kabul / Accepted: 11.05.2021, Online Yayınlanma / Published Online: 15.08.2021)

\author{
Anahtar Kelimeler \\ Bozçay Havzası, \\ Cografi bilgi sistemleri, \\ Fiziko-kimyasal, \\ Parametreler, \\ Biyolojik parametreler, \\ Su kalitesi
}

\begin{abstract}
Özet: Bu çalışmada, Burdur Gölü kapalı havzasının yıllık akışının yaklaşık \%63'ünü sağlayan Bozçay'ın yüzeysel su kalitesinin belirlenmesi ve çevresel baskılar açısından değerlendirilmesi hedeflenmiştir. Yüzeysel su kalitesi fiziko-kimyasal ve biyolojik parametreler açısından analiz edilmiş ve ilgili yönetmelikler ve standartlar kapsamında değerlendirilmiştir. Bu amaçla Bozçay üzerinde seçilen üç istasyon, Nisan 2014-Aralık 2014 dönemlerinde izlenmiş ve mevsimsel su kalitesi değiş̧imleri incelenmiştir. Çalışma kapsamında yapılan izleme sonuçları Yerüstü Su Kalitesi Yönetmeliği (10.08.2016, RG: 29797) Ek 5, Tablo 2.'de yer alan konvansiyonel parametreler üzerinden değerlendirilmiştir. Seçilen istasyonlarda, pH, sıcaklık (T), elektriksel iletkenlik (EI), çözünmüş oksijen (ÇO), nitrat azotu $\left(\mathrm{NO}_{3}-\mathrm{N}\right)$, toplam azot (TN), fosfat fosforu ( $\left.\mathrm{PO}_{4}-\mathrm{P}\right)$, toplam fosfor (TP), toplam organik karbon (TOK), çözünmüş madde (ÇM) ve askıda katı madde (AKM) parametreleri analiz edilmiştir. Fiziko-kimyasal parametre ölçüm sonuçlarına göre IST-I'de ÇO ve TP parametreleri açısından III. Kalite sınıfı olarak belirlenirken, ISTII ve IST-III'te yalnızca iletkenlik parametresi açısından II. su kalitesi olarak belirlenmiştir. Fiziko-kimyasal parametre sonuçları, biyolojik izleme sonuçları ile karşılaştırılmış, söz konusu her üç istasyon da BMWP indeksine göre orta derecede ve çok kirlenmiş su kalitesine sahip olduğu görülmüştür.
\end{abstract}

\section{Water Quality Assessment and Determination of Environmental Pressures on Bozçay Basin}

\section{Keywords}

Bozcay Basin,

Geographic information system,

Physico-chemical,

Parameters,

Biological parameters,

Water quality

\begin{abstract}
The object of this study is to determine the surface water quality of the Bozçay, which provides approximately $63 \%$ of the annual flow rate, and to evaluate it in terms of environmental pressures. Surface water quality was assessed in terms of physico-chemical and biological parameters and evaluated within the framework of the applicable regulations and standards. Three stations in the Bozçay were selected for this purpose and monitored during the period from April 2014 to December 2014. The monitoring results of the study have been evaluated over the conventional parameters in Table 2 of Annex 5 of the Surface Water Quality Regulation (10.08.2016, OG: 29797). pH, temperature (T), electrical conductivity (EC), dissolved oxygen (DO), nitrate nitrogen $\left(\mathrm{NO}_{3}-\mathrm{N}\right)$, total nitrogen (TN), phosphate phosphorus $\left(\mathrm{PO}_{4}-\mathrm{P}\right)$, total phosphorus (TP), total organic carbon (TOC), dissolved matter (DM) and suspended solids (SS) parameters were analyzed. According to the results at IST-I, water quality was determined as III. class in terms of DO and TP parameters, at IST-II and IST-III water quality was determined as II.class in terms of conductivity. The results of the parameters were correlated with the results of the biological monitoring at stations, and the BMWP index showed that the water quality was moderate and/or heavily polluted.
\end{abstract}

\section{Giriş}

Nüfusun hızla artması ve buna bağlı olarak tarımsal uygulamalar, endüstrileşme ve teknolojik gelişimler gibi nedenlerle su ihtiyacı gün be gün artmakta su kaynakları ise zamanla azalmaktadır. Ayrıca su kaynaklarındaki kirlilik ve kaynak eksiliği problemleri giderek daha büyük sorunlar 
doğurmaktadır. Sahip olduğumuz su kaynaklarından ekolojik değerlere zarar vermeden yararlanmak ve kullanımını doğru şekilde planlanıp kamu yararı gözetilerek tasarlamak gerekir. Su kaynaklarının verimli kullanımı için sürdürülebilir su yönetimi ve bunun sağlanması için ise su kaynaklarının korunması ve kullanımının yönetilmesi önemli bir unsurdur.

Hidrolojik cevrim içeresinde anakara, göller ve denizler arasında ekolojik ve ekonomik anlamda değerli olan akarsular zengin bir canlı yaşamına sahiptirler. Yaşamsal faaliyetlerden kaynaklanan kirletici unsurlar, akarsular yoluyla deniz ve göllere taşınmaktadır. Bu tür durumlar su kaynaklarını kirletilmekte ve su kaliteleri bozulmaktadır [1].

Yüzeysel su kalitesinin bilinmesi suyun hangi amaçla kullanılabileceği hakkında fikir vermektedir[2]. İnsan ve ekosistemin yaşamsal faaliyetlerini sürdürmesi açısından çok önemli olan su kalitesinin belirlenmesi, kaynakların kullanımını efektif olarak belirleyerek fiziksel, kimyasal ve biyolojik açıdan periyodik olarak izlenmesini gerektirmektedir [3]. Su kaynaklarının sürdürülebilir yönetimi için, Yerüstü $\mathrm{Su}$ Kalitesi Yönetmeliği (YSKY), su kaynaklarının korunması, yerüstü suları ile kıyı ve geçiş sularının biyolojik, fiziko-kimyasal ve hidromorfolojik kalite sınıflarının belirlenmesi, su kalitesinin izlenmesi ve kullanım amaçlarının sürdürülebilir șekilde ortaya konması, korunması ve iyi su kalitesine ulaşılması için alınacak tedbirlere yönelik usul ve esasları kapsamaktadır [28]. YSKY'nde verilen kıta içi yerüstü su kaynakları dört farklı su kalite sınıfına ayrılmıștır. Sınıf-I yüksek kaliteli sular, Sınıf-II az kirlenmiş sular, Sınıf-III kirlenmiş sular ve Sınıf-IV ise çok kirlenmiş sular olarak sınıflandırılmıştır.

Sucul canlılar, sudaki besin kaynağı, oksijen miktarı, ışık geçirgenliği gibi parametrelerden etkilenmekte ve dolayısıyla su kalitesini etkilemektedir. Makroomurgasız canlılar ise, gözle görülecek kadar büyük olmalarının yanı sıra habitatlarının sınırlı olması, su kalitesindeki değișimlerden etkilenmeleri ve yil boyu akarsuda bulunabilmeleri sebebiyle su kalitesi çalışmalarında indikatör olarak tercih edilmektedir [4].

Su kalitesi izleme çalışmaları genel olarak fizikokimyasal izlemeye dayalı yapılsa da son dönemde biyolojik izleme sayılarında da artış görünmektedir $[5,4]$. Biyolojik izleme verileri orta veya uzun vadede su kalitesi hakkında daha gerçekçi bilgiler verdiğinden fiziko-kimyasal parametrelerle birlikte biyolojik izleme verilerinin de değerlendirilmesi sonuçların güvenilirliğini yükseltmekle birlikte sucul canlıların maruz kaldığı kronik etkiler hakkında da daha detaylı bilgi edinilmesine olanak sağlamaktadır [6]. Su kalitesi; sucul canlıların varlık/yokluk, çeşitlilik veya bolluk gibi etmenlere bağlı olarak izlenebilmektedir [7].
$\mathrm{Bu}$ çalışma ülkemizin kapalı havzalarından biri olan Burdur Havzası'nda yer alan, Burdur Gölü'nü besleyen 12 alt havzadan en büyüğü olan ve Burdur Gölü kapalı havzasının yıllık akışının yaklaşık \%63'ünü sağlayan Bozçay'ın yüzeysel su kalitesinin belirlenmesini içermektedir. Söz konusu çalışmada Yerüstü Su Kalitesi Yönetmeliği Ek 5 Tablo 2.'de yer alan parametreler ve sınır değerler kullanılarak su kalite sınıfları değerlendirilmiştir. Yapılan çalışmada Fiziko-kimyasal ve Biyolojik parametre sonuçları birbirleriyle karşılaştırılarak su kalitesi belirlenmiştir. Ayrıca Bozçay üzerinde, Karaçal Barajı sonrası Burdur Gölü öncesinde bulunan DSİ 'ye ait istasyon verileri 1995-2009 yıllarını kapsayan 15 yıllık dönem için istatistiksel olarak değerlendirilmiştir. Yapılan çalışmanın sonuçları havza üzerindeki uzun yılları kapsayan DSİ su kalitesi verileri ile desteklenmiştir.

\section{Materyal ve Metot}

\section{1. Çalıșma alanı}

Burdur Havzası, Akdeniz Bölgesi'nin kuzeybatısında ve Ege Bölgesi'nin doğusunda, bulunmakta ve Göller Bölgesi olarak bilinmektedir. $37^{\circ}-38^{\circ}$ kuzey enlemleri ile $29^{\circ}-30^{\circ}$ doğu boylamları arasında bulunan kapalı bir havzadır. Toplam yağış alanı $6.284 \mathrm{~km}^{2}$ olan Burdur Havzası'nın yıllık ortalama akışı 7,94 $\mathrm{m}^{3} / \mathrm{s}^{\prime}$ dir. Havzadaki akışın yağıșa oranı 0,06 , yıllık ortalama verimi $0,91 \mathrm{~L} / \mathrm{s} / \mathrm{km}^{3}$ ve iştirak oranı $\% 0,14$ ' tür (Şekil 1).

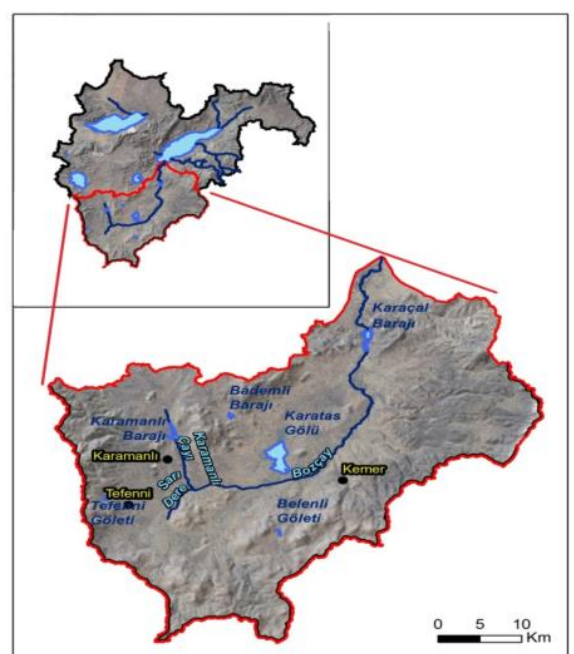

Şekil 1. Bozçay havzası coğrafi durum haritası

Sahip olduğu biyolojik çeşitliliğin yanı sıra ekonomik değeriyle de en önemli yaşam alanlarından olan sulak alanlar tüm dünyada büyük bir öneme sahiptir. Türkiye, 1971 yılında İran'ın Ramsar kentinde imzalanan sözleşmeye (Özellikle Su Kuşları Yaşama Ortamı Olarak Uluslararası Öneme Sahip Sulak Alanlar Hakkında Sözleşme) 1994 yılında taraf olmuş ve içlerinde Burdur Gölü'nün de bulunduğu 5 alan, sulak alan olarak ilan edilmiștir [8]. Burdur Gölü hem insani yaşam açısından hem de çok sayıda farklı türe 
ev sahipliği yapmasından dolayı statüsünün korunması da son derece önemli bir konudur [9]. Göl ekosisteminin iyileşmesi bölgedeki yağıșa, gölü besleyen nehirlere, ekosisteme dâhil olan canlılara ve fiziko-kimyasal faktörlere bağlıdır [10]. Önemli endemik türlerin yaşadığı ve göçmen kuşların uğrak yeri olarak uluslararası RAMSAR alanı olarak korunmaya alınan Burdur Gölü güneybatıdan giriş yapan Bozçay ile birlikte birkaç dereyle beslenmektedir [11].

Güneyde bulunan Rahat Dağı'ndaki kaynaklardan başlayıp daha sonra Karamanlı Çayı ile karıșıp, Kemer İlçesi'nin kuzeybatısından kuzeye doğru akmakta ve üzerine kurulan Karaçal Barajı'nı geçtikten sonra Burdur Gölü'ne dökülmektedir [26]. Bozçay'ın yıllık ortalama akım miktarı $62,94 \mathrm{hm}^{3}$ uzunluğu ise 85,4 km'dir [31]. Bozçay genel olarak karstik kaynaklardan beslenmektedir. Üzerinde inşa edilen Karaçal Barajı 2009 yılı sonbaharında su tutmaya başlamıștır. Yaklașık 5.000 ha alanın sulamasını sağlayan Baraj Burdur Gölü seviyesinde belirgin bir düşüşe sebep olmuştur [12].

Bozçay Havzası'nın iklimi Akdeniz iklimi ile Karasal iklim arasında geçiş özeliği taşımaktadır. Yaz mevsimleri sıcak ve kurak, kış mevsimleri ise oldukça soğuk geçmektedir. Ortalama yağış miktarı 19712000 yılları meteoroloji verilerine göre 508,7 mm'dir [29].

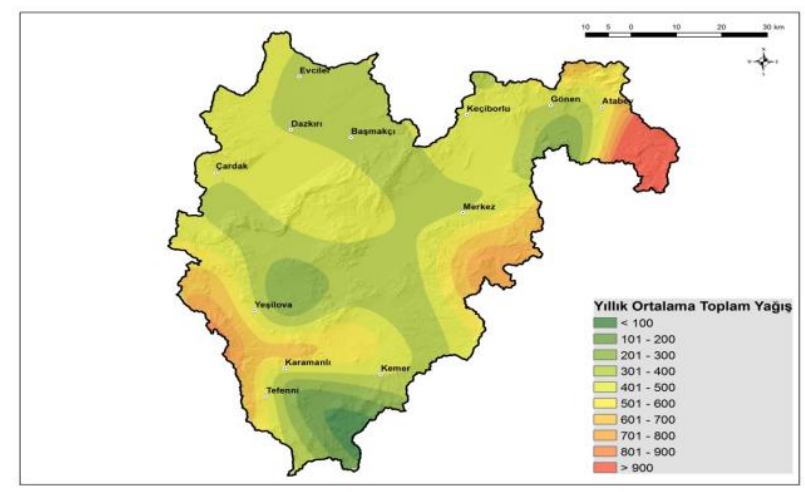

Şekil 2. Burdur havzası yıllık ortalama toplam yağış haritası
Burdur Merkez ilçesi ve Karamanlı ilçesi Bozçay Havzası içerisinde yer almaktadır. Havza, alan olarak Burdur Havzası'nın \%25'ini olușturmaktadır. Havzada yer alan Burdur Merkez ilçesi nüfusu 111.984, Karamanlı ilçesi nüfusu ise 7.982 kişidir [25]. Bozçay Havzası, yaklaşık 120.000 kişilik havza nüfusu ile Burdur Havzası'nın nüfus olarak \%45'ini oluşturmaktadır.

Meteoroloji istasyonlarında sıcaklık ve yağış ölçümlerinin değerlendirilmesi için uzun yıllar meteorolojik veriler temin edilmiștir ve istasyonların ortalama 50 yıllık veri seti kullanılmıștır. Burdur Havzası'nda yer alan istasyonlardan alınan verilere göre yıllık ortalama sıcaklık değerlerinin $10^{\circ} \mathrm{C}$ civarında olduğu görülmektedir. Ortalama sıcaklıklar bakımından hiçbir ayın ortalaması $0^{\circ} \mathrm{C}$ 'nin altına düşmemiştir. Havza sıcaklık bakımından Akdeniz ikliminden daha soğuktur. En yüksek sıcaklıklar temmuz ve ağustos aylarında, en düşük sıcaklıklar ise ocak aylarında görülmektedir. Sıcaklık bakımından istasyonlar arasında belirgin farklar olmadığı görülmüştür [30].

Ekim ayında başlayan Akdeniz'den gelen cephesel yağışlar nisan ayına kadar devam etmekte aralık ayında ise maksimum seviyeye çıkmaktadır. Bu miktar Akdeniz Bölgesi'nde bulunan istasyonlara göre çok düşüktür. Bunun nedeni, denizlerden gelen yağmur bulutlarının, havzayı güneyden çevreleyen dağları geçerek Anadolu'nun içlerine doğru gitmesidir. İlkbahar ve yaz aylarında ise bölgede konvektif yağışlar görülmektedir [34].

\subsection{Baskılar}

Havzadaki baskılar noktasal (kentsel ve endüstriyel) kaynaklı ve yayılı kaynaklı baskılar olarak incelenmiştir. Noktasal baskı olarak IST-I istasyonunun yer aldığı su kütlesinde Tefenni (10.697 kişi) ve Karamanlı (7.982 kişi) ilçelerinin kentsel deşarjları ve IST-III istasyonunun bulunduğu su kütlesinde ise Kemer ilçesi kentsel doğrudan deșarjları bulunmaktadır. Bozçay Havzası içerisinde önemli bir endüstriyel tesis bulunmamaktadır. Yayılı

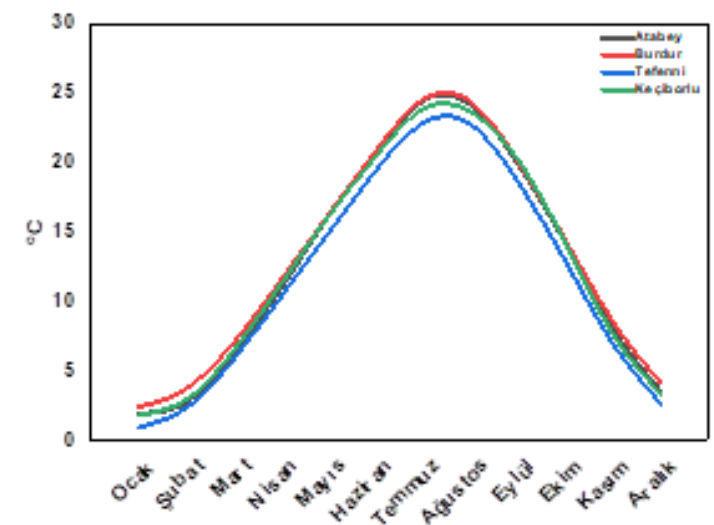

Uzun Yillar Aylik Sicakik Ortalamas:

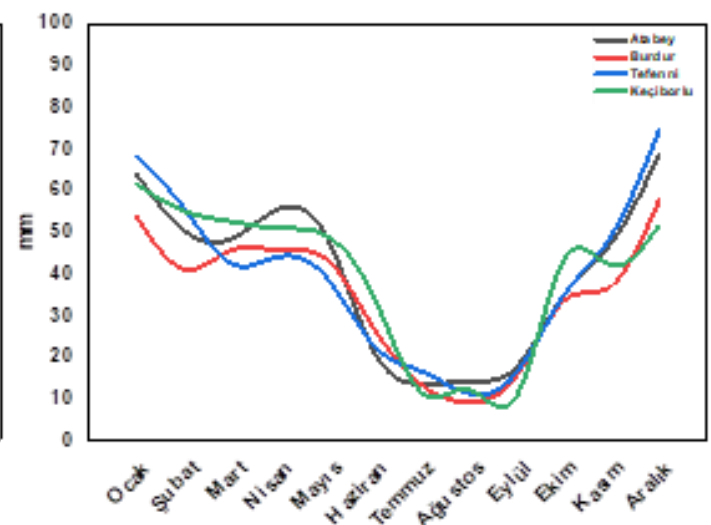

Uzun Yillar Aylik Yagh Ortalamas।

Şekil 3. Burdur havzası uzun yıllar sıcaklık ve yağış ortalamaları 
kaynaklı baskılar ile ilgili veriler incelendiğinde; havzada yapılan tarımsal faaliyetler değerlendirildiğinde bölgede genel olarak tahıl üretimi yapılmaktadır ve tahıl üretimi tarım alanlarının \%85'ini oluşturmaktadır. Havzadaki en önemli baskı unsurlarından biri olan tarımsal faaliyetler Şekil 4'te görüldüğü üzere son üç yılda artış göstermektedir.

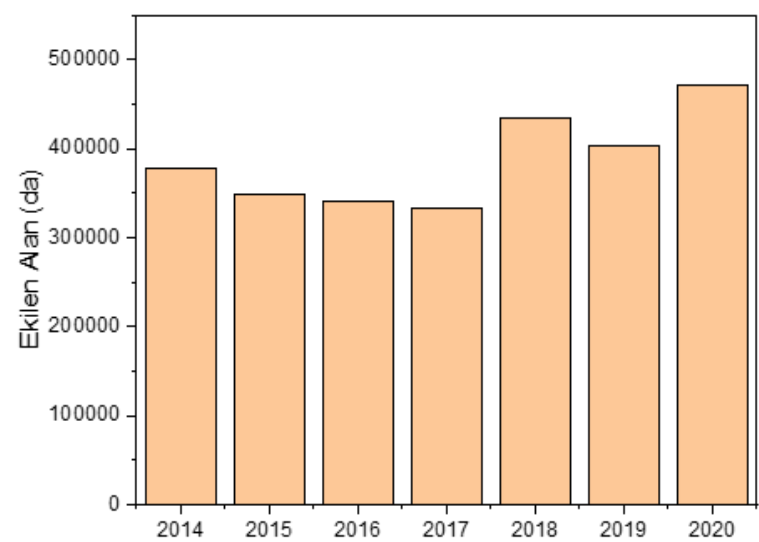

Şekil 4. Havzadaki ekilen tarım alanı [25]

TÜİK verilerine göre $2014-2020$ yılları arasında bölgede yetiştirilen büyükbaş, küçükbaş ve kümes hayvanı yetiştiriciliği sayıları Şekil 5'te verilmiştir. Hayvancılık faaliyetleri yıllara bağlı olarak çok fazla bir değişim göstermemiş olsa da en önemli baskı unsurlarından biri olarak belirlenmiștir.

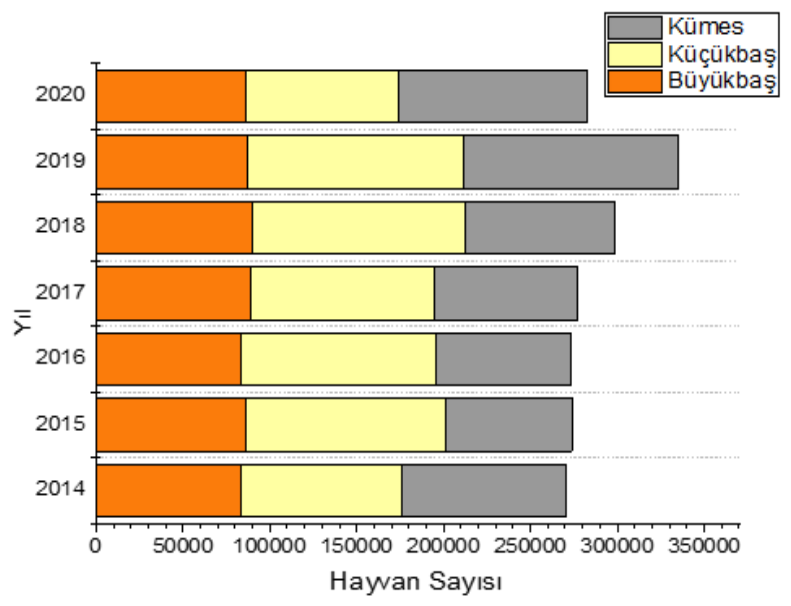

Şekil 5. 2014-2020 hayvan sayıları [25]

TN

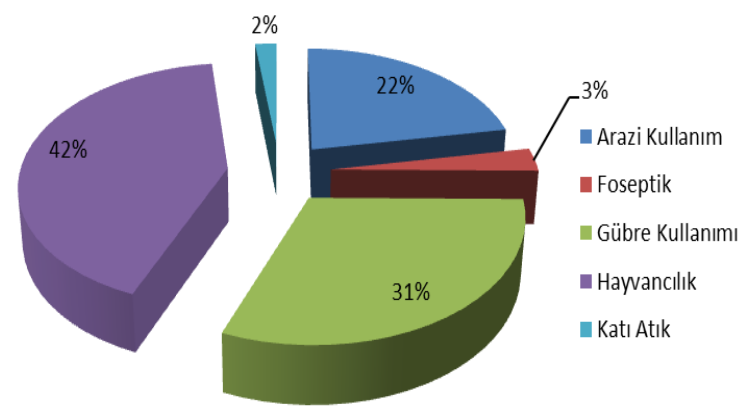

Şekil 6. Bozçay havzası yayılı TN ve TP yükleri
Bozçay Havzası noktasal ve yayılı kirlilik yükleri [13]'de verilen yöntem kullanılarak hesaplanmıştır. Bölgede noktasal kirliliğin tek kaynağl kentsel deşarjlar olup çalışma alanındaki toplam TN yükünün sadece \%2'sini ve TP yükünün ise \%7'sini oluşturmaktadır.

Yapılan hesaplamalar neticesinde, havzada en önemli baskının yayılı kaynaklı baskılar olduğu söylenebilir. Bölgedeki yayılı kaynaklı toplam azot yükünün $\% 42$ 'sini hayvancıllk ve \%31'ini tarımsal faaliyetler oluştururken, toplam fosfor yükünün \%52'si hayvancilk ve \%27'si tarımsal faaliyetler oluşturmaktadır. En önemli yayılı baskı unsurları, tarım ve hayvancılık faaliyetleri olarak belirlenmiștir (Şekil 6).

Tarımsal faaliyetlerin yanı sıra son yıllarda Karamanlı ve Burdur Merkez ilçesinde madencilik faaliyetleri de baskı unsuru olarak yer almakta ve kirliliğe sebep olmaktadır. 2017 yılında Burdur ilinde ilçelerin ruhsat defterlerine göre Maden İșletme sayılarının en çok olduğu bölgeler, 108 müessese ile Burdur Merkez $(\% 26,3)$ ve 46 müessese ile Karamanlı $(\% 11,2)$ ilçeleridir. Bu ilçelerdeki madencilik faaliyetleri ildeki faaliyetlerin \%37,5'ini oluşturmaktadır. Söz konusu ilçelerdeki ișletmeler ağırlıklı olarak mermer ocak ve işleme ile krom maden ocağ zenginleştirme işletme ruhsatlarıdır [32]. Kontrolsüz șekilde yürütülen mermercilik faaliyetleri çevresel açıdan olumsuz etkilere neden olmaktadır. Madencilik faaliyetlerinden ötürü hem yüzey hem de yeraltı suları etkilenmektedir [14]. Ayrıca mermercilik faaliyetleri bölgenin ekolojik yapısını değiştirmekte, bitki çeşitliliğinin olumsuz etkilenmesine ve habitatta yaşayan canlılar için tehlikeye de sebep olmaktadır [15].

\section{3. İzleme çalışmaları}

Bozçay üzerinde belirlenmiş olan 3 adet istasyonda 2014 yılında 4 defa (mevsimsel) fiziko-kimyasal parametrelerin izlemesi ve bir defa (yaz döneminde) seçilen biyolojik parametrelerin izleme çalıșması gerçekleştirilmiştir [24]. İzleme yapılan istasyon bilgileri Tablo 1'de verilmektedir. Biyolojik izleme çalışması kapsamında nehir kalitesini

TP

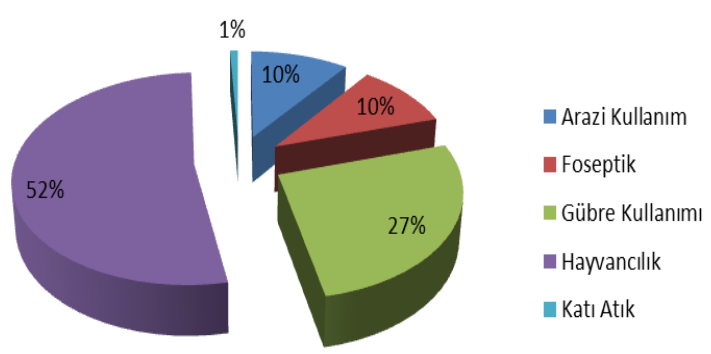


değerlendirmek üzere biyolojik parametre olarak makroomurgasizlar analiz edilerek değerlendirilmiştir.

Tablo 1. Bozçay örnek alınan istasyonlar

\begin{tabular}{cccc}
\hline $\begin{array}{c}\text { İstasyon } \\
\text { kodu }\end{array}$ & Adı & Enlem* $^{*}$ & Boylam* $^{*}$ \\
\hline IST-I & Sarı Dere & $29^{\circ} 51^{\prime} 49.800^{\prime \prime} \mathrm{E}$ & $37^{\circ} 19^{\prime} 57.300^{\prime \prime} \mathrm{N}$ \\
IST-II & Bozçay & $29^{\circ} 57^{\prime} 19.100^{\prime \prime} \mathrm{E}$ & $37^{\circ} 20^{\prime} 35.500^{\prime \prime} \mathrm{N}$ \\
IST-III & Bozçay & $30^{\circ} 4^{\prime} 31.400^{\prime \prime} \mathrm{E}$ & $37^{\circ} 30^{\prime} 52.200^{\prime \prime} \mathrm{N}$ \\
\hline
\end{tabular}

\subsection{Fiziko-kimyasal parametreler}

Çalışmada; fiziko-kimyasal parametrelerden $\mathrm{pH}$, sıcaklık, ÇO, TOK, AKM, TN, TP, $\mathrm{PO}_{4}-\mathrm{P}, \mathrm{NH}_{3}-\mathrm{N}, \mathrm{NO}_{2}-\mathrm{N}$ ve $\mathrm{NH}_{4}-\mathrm{N}$ parametreleri izlenmiștir. Her bir istasyondan alınan farklı hacim, koruma ve saklama koşullarında olan su örnekleri, Yer Üstü Suları, Yer Altı Suları ve Sedimentten Numune Alma ve Biyolojik Örnekleme Tebliği'ne uygun olarak örneklenmiş ve muhafaza edilmiştir [35]. Tüm analizler, TÜBİTAK MAM Çevre ve Temiz Üretim Enstitüsü'nde ISO 17025'e göre akreditasyona sahip laboratuvarlarında analiz edilmiştir. Proje kapsamında yapılan izleme çalışmalarında, numune alımı ve analizler için izlenen yöntemler, uluslararası standart yöntemlerdir. Analizler Tablo 2'de belirtilen cihaz ve yöntemlere göre yapılmıştır.

Tablo 2. İzlenen parametreler ve kullanılan yöntemler

\begin{tabular}{|c|c|c|}
\hline Parametre & Yöntem & $\begin{array}{l}\text { Tespit } \\
\text { Limiti }\end{array}$ \\
\hline $\mathrm{pH}$ & SM $4500 \mathrm{H}+\mathrm{B}$ & - \\
\hline İletkenlik & SM 2510 B & - \\
\hline Çözünmüş $\mathrm{O}_{2}$ (ÇO) & SM 4500 o, G & - \\
\hline Amonyum azotu $\left(\mathrm{NH}_{4}{ }^{+}-\mathrm{N}\right)$ & $\mathrm{SM} 4500-\mathrm{NH}_{3} \mathrm{H}$ & $0,003 \mathrm{mg} / \mathrm{L}$ \\
\hline $\begin{array}{l}\mathrm{Nitrit}+\mathrm{Nitrat} \text { azotu } \\
\left(\mathrm{NO}_{2}+\mathrm{NO}_{3}-\mathrm{N}\right)\end{array}$ & $\mathrm{SM} 4500 \mathrm{NO}_{3^{-}}: \mathrm{I}$ & $0,003 \mathrm{mg} / \mathrm{L}$ \\
\hline $\begin{array}{l}\text { Toplam Kjeldahl azotu } \\
\text { (TKN) }\end{array}$ & SM-4500 N org. & $0,15 \mathrm{mg} / \mathrm{L}$ \\
\hline Toplam Fosfor (TP) & SM 4500 P: H & $0,008 \mathrm{mg} / \mathrm{L}$ \\
\hline Fosfat Fosfor $\left(\mathrm{PO}_{4}-\mathrm{P}\right)$ & SM 4500 P: H & $0,008 \mathrm{mg} / \mathrm{L}$ \\
\hline
\end{tabular}

\subsection{Biyolojik parametreler}

Bölgede biyolojik izleme yöntemiyle su kalitesini ortaya çıkarmak için diğer Avrupa indeksleri ile de yüksek korelasyon gösteren ve uygulaması kolay olan
Biological Monitoring Working Party (BMWP) biyotik indeksi uygulanmıștır [16].

Tablo 3. BMWP skor aralıkları ve kategorileri

\begin{tabular}{ccc}
\hline BMWP Skoru & Kategori & Sınıf \\
\hline $0-10$ & Çok kötü su kalitesi & V \\
$11-40$ & Kötü su kalitesi & IV \\
$41-70$ & Orta derecede su kalitesi & III \\
$71-100$ & İyi & II \\
$>100$ & Çok temiz & I \\
\hline
\end{tabular}

Bu çalışmada Bozçay'da izleme istasyonlarında tespit edilen makroomurgasızlar için BMWP sonuçları hesaplanmıştır. Her bir örnekleme noktasından prosedürlere uygun şekilde örneklemesi ve teşhisleri yapılmış bireylerin BMWP skorları toplanarak hesaplanmıștır. Genelde >100 üzerinde olan değerler temiz su, <10 altında olan değerler kirli su olarak nitelendirilmekte olup BMWP skor aralıkları ve kategorileri Tablo 3.'te verilmiştir.

\section{Bulgular}

\subsection{Fiziko-kimyasal değerlendirilmesi}

parametrelerin

$\mathrm{Bu}$ çalıșmadaki değerlendirmeler, belirlenmiş olan istasyonlarda su kalite sinıfları, 4 dönem (mevsimlik) yapılan ölçümlerin aritmetik ortalama değerleri alınarak belirlenmiştir. İstasyonlara ait ölçülen fizikokimyasal parametrelerin analiz sonuçları Tablo 4'te verilmektedir.

Sicaklık, su ortamında oluşan biyokimyasal reaksiyonların hızını ve gazların çözünürlüğünü özellikle oksijen miktarını etkilemesi açısından sucul yaşam için oldukça önemli bir parametredir. Ayrıca suda yaşayan canlıların yaşamsal faaliyetlerine de etki etmektedir [17]. Şekil 7(a)'da görüldüğü gibi sıcaklık parametresi mevsimsel olarak değişmektedir. En yüksek sıcaklık yaz ayı örneklemesinde $15-20{ }^{\circ} \mathrm{C}$ olarak ölçülürken en düşük sıcaklık kış ayı örneklemesinde $7-13{ }^{\circ} \mathrm{C}$ arasında ölçülmüştür.

pH sularda asidik ve bazik özelliğinin bir göstergesidir [18]. YSKY'ne göre 6-9 pH aralığına

Tablo 4. Bozçay'da ölçülen fiziko-kimyasal parametrelerin Analiz Sonuçları

\begin{tabular}{|c|c|c|c|c|c|c|c|c|c|c|c|c|c|}
\hline \multirow{2}{*}{ Parametre } & \multirow{2}{*}{ Birim } & \multirow{2}{*}{$\begin{array}{l}\text { Ölçüm } \\
\text { Limiti }\end{array}$} & \multicolumn{3}{|c|}{ IST-I* } & \multicolumn{4}{|c|}{ IST-II } & \multicolumn{4}{|c|}{ IST-III } \\
\hline & & & Bahar & Yaz & Kış & Bahar & Yaz & Güz & Kıș & Bahar & Yaz & Güz & Kıș \\
\hline Sicaklık & ${ }^{\circ} \mathrm{C}$ & -- & 16,20 & 16,20 & 7,60 & 16,40 & 19,90 & 15,60 & 14,00 & 15,90 & 18,00 & 16,00 & 11,80 \\
\hline & - & -- & 8,17 & 7,25 & 8,50 & 7,98 & 7,83 & 8,15 & 7,70 & 8,08 & 8,00 & 8,10 & 8,15 \\
\hline İletkenlik & $\mu \mathrm{s} / \mathrm{cm}$ & -- & 374 & 459 & 251 & 409 & 414 & 761 & 348 & 1024 & 750 & 835 & 592 \\
\hline Çözünmüş Oksijen & $\mathrm{mg} / \mathrm{L}$ & -- & 4,30 & 4,26 & 4,50 & 8,46 & 8,35 & 7,45 & 8,50 & 10,30 & 7,30 & 7,50 & 7,60 \\
\hline $\mathrm{NH}_{4}^{+}-\mathrm{N}$ & $\mathrm{mg} / \mathrm{L}$ & 0,01 & 0,02 & 1,31 & 1,40 & 0,01 & 0,12 & $<0,01$ & 0,00 & 0,01 & 0,00 & 0,10 & 0,01 \\
\hline $\mathrm{NO}_{3}-\mathrm{N}$ & $\mathrm{mg} / \mathrm{L}$ & 0,01 & 0,33 & 1,16 & 0,50 & 1,26 & 1,27 & 1,64 & 1,60 & 1,30 & 0,30 & 0,60 & 1,65 \\
\hline Toplam Fosfor & $\mathrm{mg} / \mathrm{L}$ & 0,01 & 0,02 & 0,41 & 0,10 & $<0,01$ & 0,01 & 0,01 & 0,00 & $<0,01$ & 0,00 & 0,00 & 0,01 \\
\hline Toplam Çözünmüş Madde & $\mathrm{mg} / \mathrm{L}$ & -- & 221 & 225 & 182 & 241 & 240 & 257 & 215 & 617 & 423 & 510 & 383 \\
\hline Askıda Katı Madde & $\mathrm{mg} / \mathrm{L}$ & 5 & 19 & 12 & 6 & 12 & 5 & 772 & 59 & 5 & 39 & 89 & 76 \\
\hline TOK & $\mathrm{mg} / \mathrm{L}$ & 0,50 & 7,02 & 5,90 & 4,20 & 5,96 & 5,03 & 2,44 & 3,00 & 16,08 & 4,30 & 3,30 & 6,91 \\
\hline Toplam Azot & $\mathrm{mg} / \mathrm{L}$ & 0,01 & 0,54 & 2,91 & 2,20 & 1,36 & 1,42 & 1,70 & 1,60 & 1,67 & 0,70 & 0,90 & 1,71 \\
\hline $\mathrm{PO}_{4}^{3-}-\mathrm{P}$ & $\mathrm{mg} / \mathrm{L}$ & 0,01 & $<0,01$ & 0,38 & 0,10 & $<0,01$ & $<0,01$ & $<0,01$ & 0,00 & $<0,01$ & 0,00 & 0,00 & $<0,01$ \\
\hline
\end{tabular}


sahip sular I. Kalite su olarak tanımlanmaktadır. İstasyonlarda anlık olarak ölçülen pH değerlerine göre tüm istasyonlar su kalitesi açısından I. kalite su için verilen değer aralığında kaldığı $(7,25-8,50)$ ve nötr ile hafif alkali karakterde olduğu söylenebilir (Şekil 7 (b)).

Mineral maddelerin ve çözünmüş tuzların etkisi ile oluşan elektriksel iletkenlik, ölçüm yapılan istasyonlar içinde en yüksek değer IST-II İstasyonunda bahar döneminde tespit edilmiştir $(1024 \mu \mathrm{S} / \mathrm{cm})$. En düşük elektriksel iletkenlik değeri ise IST-I İstasyonunda kış döneminde $(490 \mu \mathrm{S} / \mathrm{cm})$ belirlenmiştir. İletkenlik, kirliliğin yanı sıra jeolojik

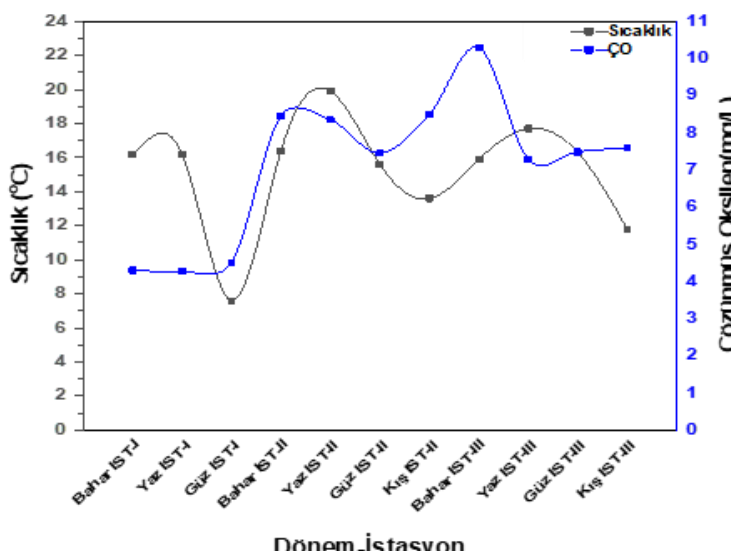

(a)

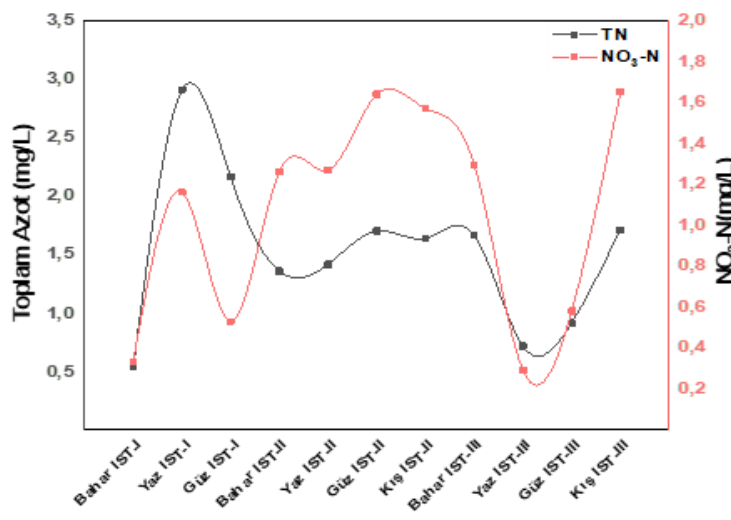

Donem-istasyon

(c)

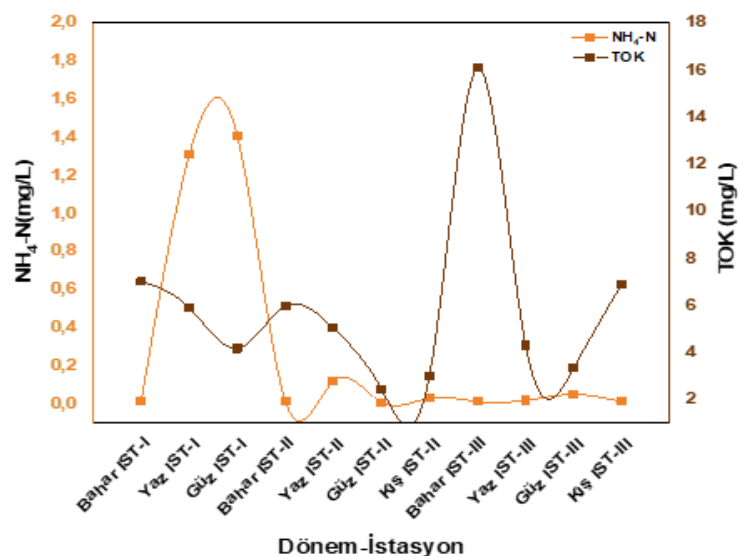

(e) etkilere de bağlıdır [19]. İletkenlik değerlerinin yüksek değerde çıkmasının jeolojik yapıdan kaynaklandığı düşünülmektedir. Çünkü iletkenlik değerlerinde artış gözlenirken diğer parametreler I. kalite su sınıfı değerlerini ifade etmektedir. İletkenlik ölçüm sonuçları değerlendirildiğinde IST-I istasyonu I. Kalite, IST-II ve IST-III istasyonu II. su kalite sınıfına girmiştir.

Çözünmüş oksijen (ÇO) konsantrasyonu suyun kirlenme derecesi ve organik madde konsantrasyonu hakkında bilgi vermektedir [20]. ÇO için IST-I istasyonunda (Sarıdere) ölçülen konsantrasyonun mevsimsel ortalaması 4,30 olup ÇO değerlerine göre

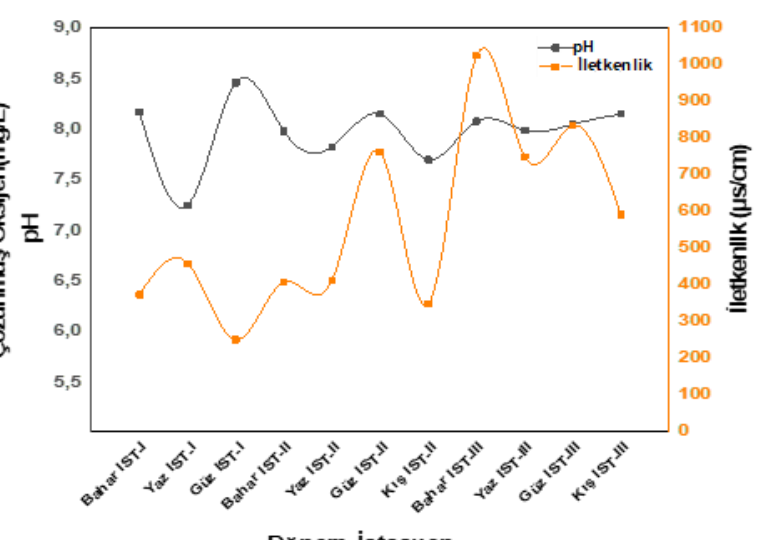

(b)

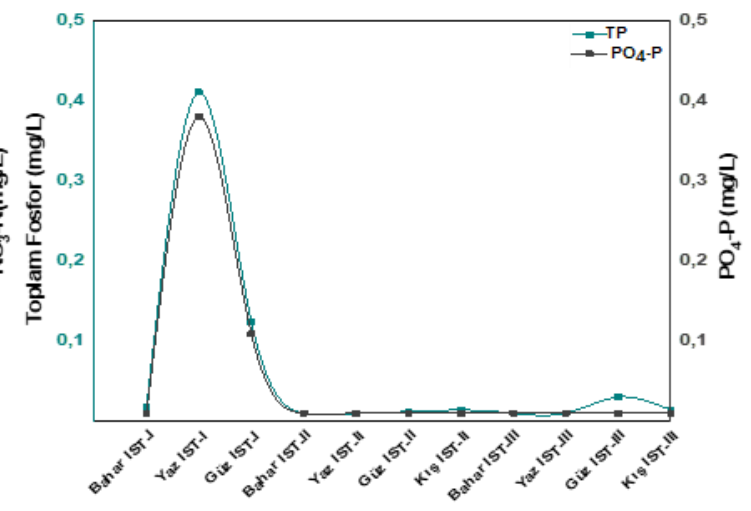

Dönem-istasyon

(d)

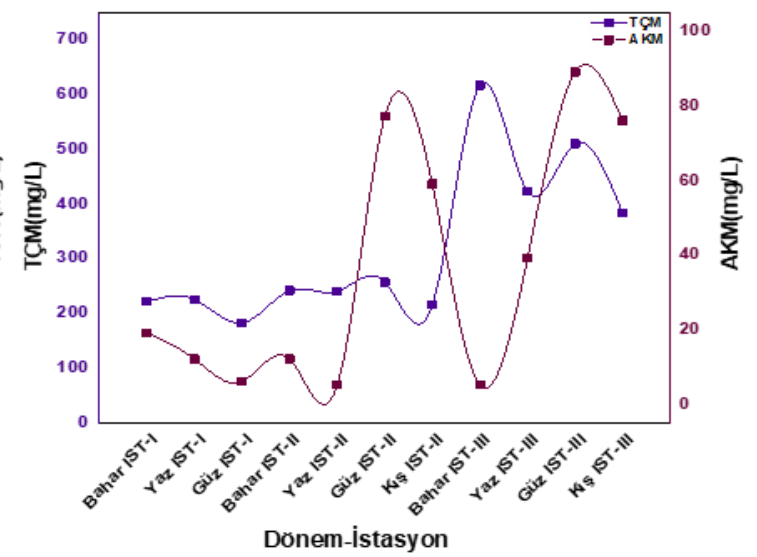

(f)

Şekil 7. Bazı parametrelerin mevsimsel izleme sonuçları (a) sıcaklık-çözünmüş oksijen, (b) iletkenlik-pH, (c)TN,NO $3-\mathrm{N},(\mathrm{d}) \mathrm{TP}^{-} \mathrm{PO}_{4}-$ $\mathrm{P},(\mathrm{e}) \mathrm{NH}_{4}-\mathrm{N}-\mathrm{TOK}$, (f) TÇM-AKM 
su kalitesi III. sınıf olarak belirlenmiştir. IST-II istasyonu güz döneminde II.kalite diğer dönemlerde I.kalite sınıfı olarak tespit edilmiştir. IST-III istasyonu ölçüm sonuçları değerlendirildiğinde ise yaz, güz, kış dönemleri için ölçüm değerleri II. kalite seviyesinde belirlenmiştir.

Nitrat, amonyum ve organik azotlu bileşikler doğal sularda yaygin olarak bulunan azot formları olup su kalitesi hakkında bilgi vermektedir. Azotlu bileşiklerin en önemli kaynakları evsel, endüstriyel faaliyetler ile tarım ve hayvancılık faaliyetleridir. Azot birleşikleri su kirliliğinde önemli etkilere sahiptir ve ötrofikasyona etkisi oldukça fazladır [21]. Bozçay'da nitrat azotu değerlerine bakıldığında, nitrat azotu konsantrasyonları, YSKY kalite kriterleri sınır değerlerinden düşük tespit edilmiş olup nitrat azotu açısından tüm istasyonlar I. Sınıf su kalitesi olarak belirlenmiştir.

$\mathrm{NH}_{4}-\mathrm{N}$ parametresi IST-I istasyonunda yaz ve kış dönemi örneklemelerinde 1,30-1,40 mg/L aralığında analiz edilerek bu dönemlerde III. sınıf su kalitesine sahip olduğu belirlenmiştir. IST-II ve IST-III istasyonları ise tüm dönemlerde YSKY'ne göre I. sınıf olarak tespit edilmiștir.

Fosfor, ötrofikasyona sebep olan sinırlayıcı besin maddelerinden en önemlisi olup evsel, endüstriyel ve tarımsal faaliyetler sonucu su kaynaklarına ulaşmaktadır [22, 23]. Yapılan toplam fosfor ölçümlerinde IST-I noktasında yaz dönemi örneklemesinde $0,41 \mathrm{mg} / \mathrm{L}$, güz döneminde ise 0,12 mg/L olarak ölçülmüştür. Diğer noktalardaki toplam fosfor değeri 0,03 $\mathrm{mg} / \mathrm{L}$ 'den daha az konsantrasyonlarda bulunmuştur. Fosfor değeri yağışlı dönemlerde seyrelme faktöründen dolayı daha düşük konsantrasyonlarda analiz edilmektedir. Sonuçlar yönetmelikle karşılaştırıldığında IST-I istasyonunun fosfor açısından su kalitesinin III. sınıf, IST-II ve IST-III istasyonlarında I. sınıf olduğu belirlenmiştir.

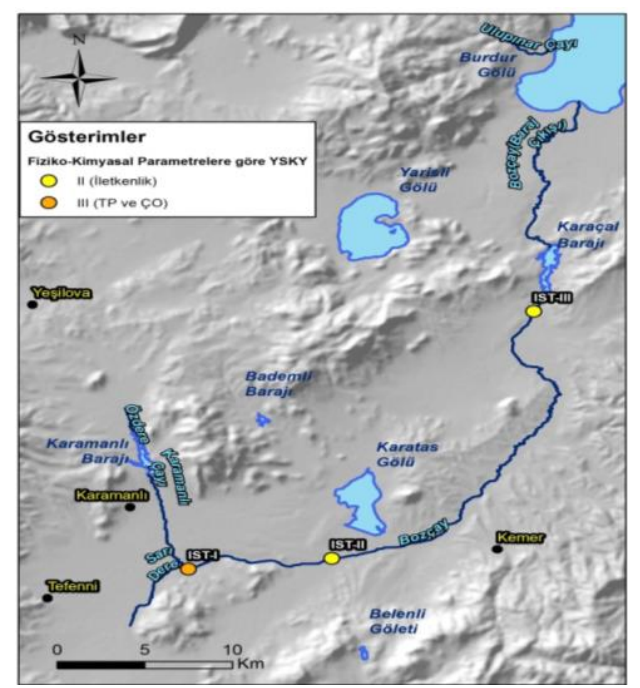

Şekil 8. YSKY'ne göre istasyonlarda fiziko-kimyasal parametreler için kalite sınıfları
Sonuç olarak, izlemesi yapılan parametreler açısından ortalama sonuçları değerlendirildiğinde IST-I istasyonu III. kalite sinıfı, IST-II istasyonu II. kalite sinıfi ve IST-III istasyonu II. kalite sınıfı göstermektedir (Şekil 8.). IST-I istasyonunun $\mathrm{NH}_{4}-\mathrm{N}$, toplam fosfor ve orto fosfat fosforu açısından III.sınıf su kalitesi özellik göstermesinin sebebinin Tefenni ve Karamanlı ilçelerinin kentsel doğrudan deşarjları olabileceği düşünülmektedir.

2019 yılında yapılmış olan Burdur Nehir Havzası Yönetim Planı Projesi kapsamında izlenmiş olan istasyonlar bu çalışma konusu istasyonlar ile uyumlu olarak görülmektedir. 2019 yılında yapılan bu çalışmada, IST-I, IST-II ve IST-III için yapılan güncel analiz sonuçlarına göre fiziko-kimyasal parametreler açısından her üç istasyonda da su kalitesi II. sınıf (az kirlenmiş su) olarak belirlenmiştir [33].

Çalışmamız kapsamında Bozçay üzerinde Karaçal Barajı çıkışında bir istasyon bulunmamakta ancak Bozçay'ın Burdur Gölü'ne bağlantı noktasında Karaçal Barajı sonrasındaki su kalitesinin değerlendirilmesi de önem taşımaktadır. Bu nedenle söz konusu noktada bulunan DSİ su kalitesi izleme istasyonunun 1995-2009 yılları arasındaki analiz sonuçları değerlendirilmiștir. Karaçal Barajı çıkışında (Burdur Gölü'ne giriş öncesinde) yer alan istasyon için toplamda 15 yıllık DSİ izleme verisi değerlendirilmiş ve Şekil 9'da grafiklendirilmiştir.

Veriler değerlendirildiğinde sıcaklık parametresinin mevsimsel düzeylerde seyrettiği, ÇO konsantrasyonunun ise son ylllarda düşüş eğiliminde olduğu görülmüştür. 15 yll boyunca ölçülen en yüksek ÇO değeri 11,50 mg/L olup sicaklığında en düşük olduğu dönem olan 2001 yılında kaydedilmiştir. Özellikle yaz dönemlerinde ÇO konsantrasyonunun azaldığı ve bu parametreye göre su kalite sınıfının II. kalite olduğu belirlenmiştir.

Nitrat azotu parametresi açısından değerlendirildiğinde yalnızca 1995 yılında en yüksek konsantrasyon seviyesi olan $5,90 \mathrm{mg} / \mathrm{l}$ olarak ölçülmüş kalan 14 yıllık ölçüm verilerinde 1,30-1,40 $\mathrm{mg} / \mathrm{L}$ civarlarında seyrettiği yani Nitrat azotu açısından I.sınıf su kalitesine sahip olduğu belirlenmiştir.

Amonyum azotu konsantrasyonu değerlendirildiğinde ise 2000 yılında 2,59 mg/L olarak ölçülmüş en yüksek değer haricinde, ortalama konsantrasyonu 0,22 mg/L olup su kütlesi II. kalite su sınıfında olduğu belirlenmiştir.

TP parametresi ise istasyonda sadece 2007 yılında 1 yll boyunca analiz edilmiş ve bu nedenle istatistiksel olarak değerlendirilmemiştir. Dört dönem verisine göre TP konsantrasyonu 0,04-0,12 mg/L arasında ölçülmüş ve bu parametre açısından da su kalitesinin II. sinıf olduğu görülmüştür. 

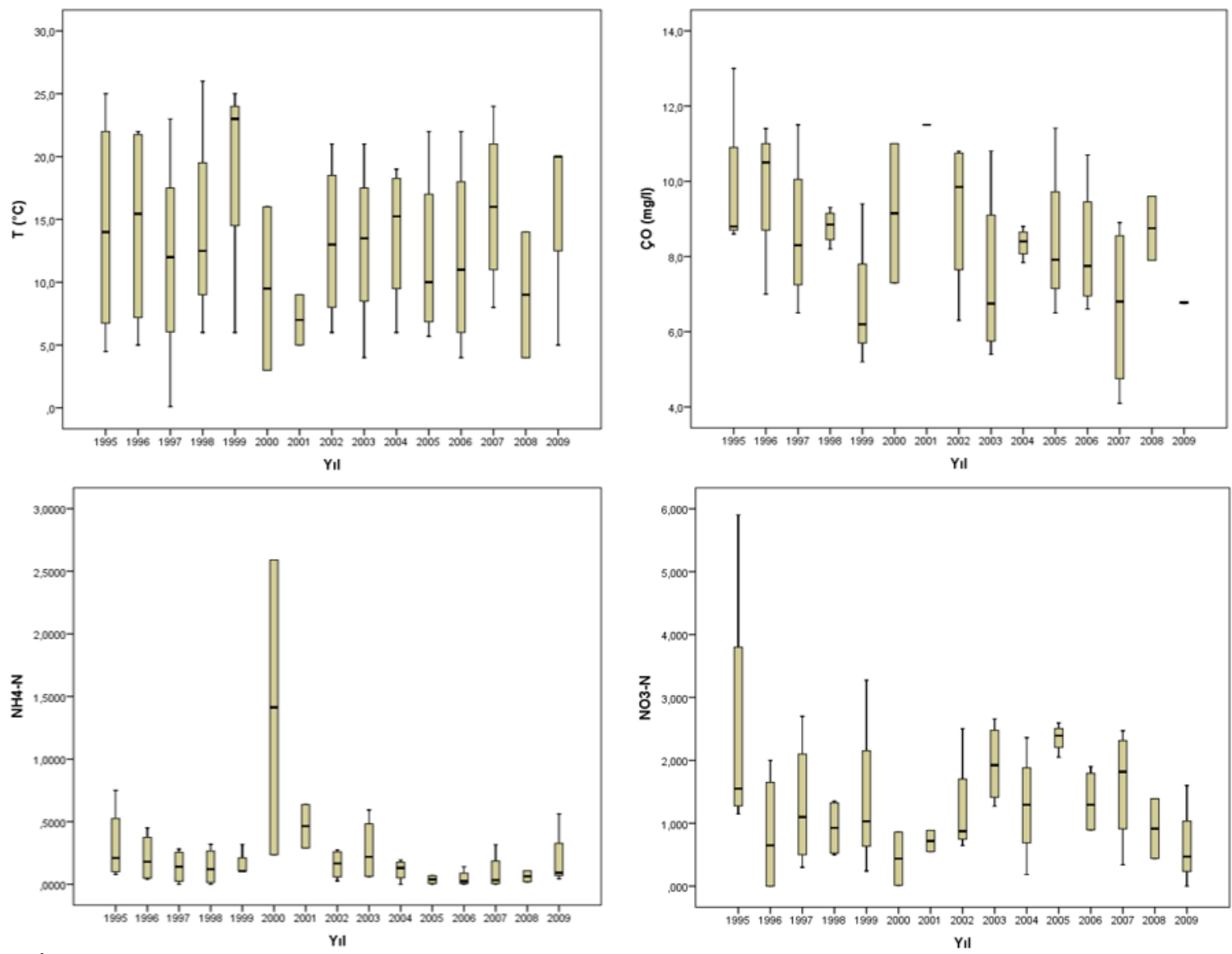

Şekil 9.DSİ Bozçay kalite gözlem istasyon veri değerlendirilmesi

Sonuç olarak, DSİ istasyonuna ait 1993-2009 tüm mevsimsel veriler değerlendirilerek istasyonun su kalitesi amonyum azotu ve toplam fosfor açısından II. kalite su sınıfına sahip olduğu görülmüştür [27].

\subsection{Biyolojik izleme sonuçlarının değerlendirilmesi}

IST-I istasyonunda fiziko-kimyasal parametreler için nihai su kalite sınıfı ortalama değerler baz alınarak ÇO, TP, $\mathrm{NH}_{4}-\mathrm{N}$ ve orto fosfat fosforu'na göre III. kalite sınıfı, İletkenlik ve $\mathrm{NH}_{4}$-N'ye göre II. kalite ve diğer parametreler için ise I. kalite sınıfi olarak belirlenmiştir. Yaz döneminde bahar dönemine göre kirlilikte artış kaydedilmiștir (Tablo 2). Fizikokimyasal parametreler açısından III. kalite su sınıfı olarak belirlenmiş olan bu istasyon için biyolojik izlemede 9 takson belirlenmiș ve en baskın takson Chironomidae familyası olmuştur. Yapılan biyolojik kalite değerlendirmesine göre BMWP indeksinde IV. su kalite sinifi olarak belirlenen istasyon orta derecede kirlenmiș akarsu bölümü yani en kirli sınıfın bir alt sınıfı olarak belirlenmiştir.

IST-II istasyonunda fiziko-kimyasal parametreler için nihai su kalite sınıfı ortalama İletkenlik parametresi ölçüm değerlerine göre II. Kalite olarak belirlenmiștir. Biyolojik izleme çalıșmalarında 4 farklı takson belirlenmiş ve IST-I'de olduğu gibi en baskın takson Chironomidae familyası olmuş ve BMWP indeksinde IV. su kalite sınıfı olan orta derecede kirlenmiş su kütlesi olarak belirlenmiștir.

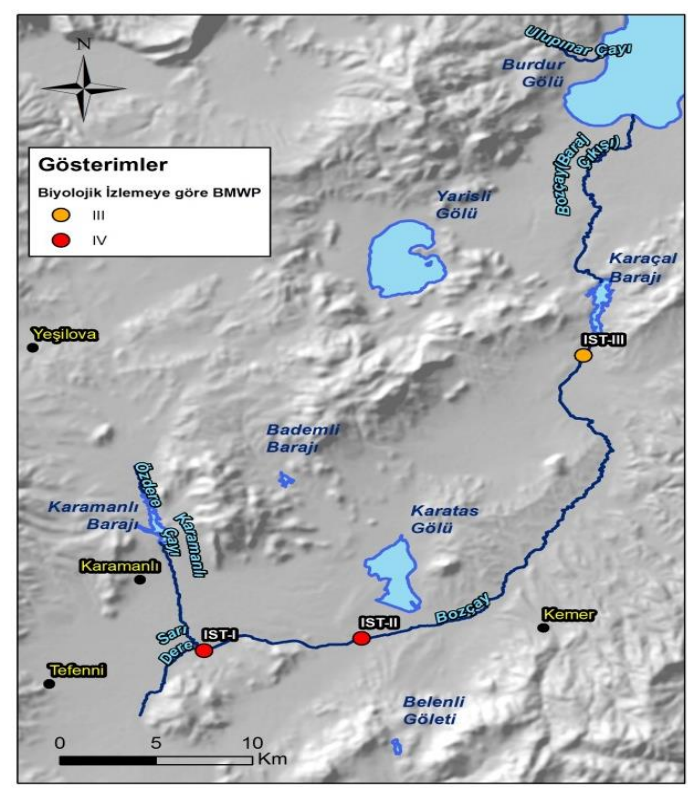

Şekil 10. Biyolojik izleme çalışmaları için BMWP indeksine göre su kalite sinıfları

IST-III istasyonunda ise yine IST-II istasyonunda olduğu gibi yalnızca iletkenlik parametresi açısından II. kalite sınıfı olarak belirlenmiş, biyolojik izleme sonucu 9 farklı takson belirlenmiştir, baskın takson sınıfı Gammaridae familyası olup BMWP indeksine 
göre ise III. su kalite sınıfı olduğu görülmüştür (Şekil 10).

Biyolojik parametreler açısından IST-I ve IST-II istasyonunun IV. Sinıf su kalitesi ve IST-III istasyonun III.sınıf su kalitesi çıkmasının sebebi bu bölgede yer alan yerleşimlerin arıtılmaksızın doğrudan yapılan kentsel deşarjların su kütleleri üstünde yarattığı uzun dönemli baskı olduğu düşünülmektedir.

Burdur NHYP Projesi (2019) kapsamında yapılan biyolojik çalışmada Bozçay üzerinde aynı koordinata sahip istasyonlar kullanılmış ve su kalitesi tüm istasyonlar için makroomurgasız canlılar açısından III. sınıf (orta kalite) olarak tespit edilmiştir. Bozçay'ın Burdur Gölü'ne girmeden önce ise bir adet NHYP projesi kapsamında izlenen istasyon mevcuttur ve Burdur Gölü'ne giriş öncesi bu istasyonda yapılan biyolojik izleme sonucu su kütlesinin III. Sınıf (zayıf kalitede) olduğu belirlenmiștir [33].

\section{Tartışma ve Sonuç}

Mevcut çalışma ile Burdur Gölü kapalı havzasının yıllık akışının yaklaşık \%63'ünü sağlayan Bozçay Havzası'nın yüzeysel su kalitesi fiziko-kimyasal ve biyolojik parametreler açısından analiz edilmiş ve ilgili yönetmelikler ve standartlar kapsamında değerlendirilmiştir. Elde edilen sonuçlar ışığında aşağıdaki sonuçlar elde edilmiştir.

- IST-I fiziko-kimyasal parametreler açısından III. sınıf (orta kirlenmiş su), IST-II ve IST-III istasyonları ise II. sınıf (az kirlenmiş) su kalitesine sahip su kütlesi olarak tespit edilmiştir. Bozçay'da Burdur Gölü'ne dökülmeden önce DSİ tarafından izlenen istasyon verileri ile karşılaştırıldığında ise fiziko-kimyasal parametreler açısından akarsuyun benzer özellikler gösterdiği ve akarsu boyunca su kalitesi açısından büyük farklılık görülmediği belirlenmiștir.

- IST-I fiziko-kimyasal parametreler açısından III. sınıf, elde edilen BMWP değerlerine göre ise IV. kalite sınıfı olarak belirlenmiş ve bu su kütlesi çok kirlenmiş su kütlesi olarak tespit edilmiştir. IST-II istasyonu fiziko-kimyasal parametreler açısından II. sınıf su kalitesine sahip su kütlesi olarak belirlenmiş fakat BMWP indeksine göre IV. kalite sınıfı olan çok kirlenmiş su kütlesi sınıfına girmiştir. IST-III istasyonu ise fiziko-kimyasal parametreler açısından IST-II'de olduğu gibi II. sınıf su kalitesine sahip olduğu tespit edilmiş fakat BMWP indeksine göre orta derecede kirlenmiş akarsu bölümünü ifade eden III. sınıf su kalitesine sahip su kütlesi olarak belirlenmiştir. Biyolojik parametreler açısından IST-I ve IST-II istasyonunun IV. Sinıf su kalitesi ve IST-III istasyonun III.sınıf su kalitesi çıkmasının sebebi bu bölgede yer alan yerleşimlerin arıtılmaksızın doğrudan yapılan kentsel deşarjların su kütleleri üstünde yarattığı uzun dönemli baskı olduğu düşünülmektedir.

Çalıșmada sunulan sonuçlar ile Burdur Gölü kapalı havzasının yıllık akışının yaklaşık \%63'ünü sağlayan Bozçay'ın yüzeysel su kalitesi değerlendirilmiş ve çevresel baskılar açısından incelenmiştir. Yapılan çalışmayla fiziko-kimyasal parametreler açısından hem mevsimsel veriler ve hem de uzun süreli veriler birlikte değerlendirilmiş, ayrıca biyolojik çalışmalar da dikkate alınarak Bozçay'ın yüzeysel su kalitesinin durumu ortaya konmuştur. Bu çalışmanın havzada çalışan ilgili araştırmacılar için bir yol haritası çizeceği umulmaktadır. Ayrıca izleme çalışmalarının sürekliliğinin esas olması, diğer taraftan da kirlenmeye neden olan unsurların karar vericiler ve uygulayıcılar tarafından bir an önce çözüme kavuşması sonucunda su kalitesinin iyi duruma ulaşması gerektiği düşünülmektedir.

\section{Teșekkür}

Mevcut çalışma, Mülga Orman ve $\mathrm{Su}$ İşleri Bakanlığınca desteklenen ve TÜBİTAK MAM Çevre ve Temiz Üretim Enstitüsü bünyesinde gerçekleştirilen Proje verilerinden türetilmiştir. Çalışmaya desteklerinden ötürü $\mathrm{Su}$ Yönetimi Genel Müdürlüğüne, veri temininden dolayı DSI'ye, biyolojik çalışmalar için ilgili akademisyenlere, teknik destekleri için TÜBİTAK MAM Proje Ekibi, Laboratuvar Ekibi ve CBS Ekibine teşekkür ederiz.

\section{Etik Beyanı}

Bu çalışmada, "Yükseköğretim Kurumları Bilimsel Araştırma ve Yayın Etiği Yönergesi" kapsamında uyulması gerekli tüm kurallara uyulduğunu, bahsi geçen yönergenin "Bilimsel Araştırma ve Yayın Etiğine Aykırı Eylemler" başlığı altında belirtilen eylemlerden hiçbirinin gerçekleştirilmediğini taahhüt ederiz.

\section{Kaynakça}

[1] Firidin, E. 2015. Su sorununun, su hakkı ve su etiği çerçevesinde değerlendirilmesi. Aksaray Üniversitesi İktisadi ve İdari Bilimler Fakültesi Dergisi, 7(2), 43-55.

[2] Topal, M., Arslan Topal, E. I. 2015. Caro Deresi (Elazığ)' nin Fizikokimyasal Parametreler Açısından Su Kalitesinin Belirlenmesi. Bitlis Eren Üniversitesi Fen Bilimleri Dergisi, 4(1), 43-53.

[3] Taş, B. 2006. Derbent Baraj Gölü (Samsun) su kalitesinin incelenmesi. Ekoloji, 16, 6-15.

[4] Uyanık, S., Cebe, A. 2017. AB Su Çerçeve Direktifi Kapsamında Biyolojik Kalite Unsurları ile $\mathrm{Su}$ Kalitesinin izlenmesi. Harran Üniversitesi Mühendislik Dergisi, 2(3), 64-72.

[5] Enis, A., Dalkıran, N., Şükran, D. 2018. Akarsuların Biyolojik $\mathrm{Su}$ Kalitesinin 
Belirlenmesinde Bentik Makroomurgasızların Kullanımı, İklim Değişikliği ve Çevre, 3(1), 6067.

[6] Sukatar, A., Yorulmaz, B., Ayaz, D., Barlas, M. 2006. Emiralem Deresi'nin (İzmir-Menemen) bazı fiziko-kimyasal ve biyolojik (Bentik Makroomurgasızlar) özelliklerinin incelenmesi. Süleyman Demirel Üniversitesi Fen Bilimleri Enstitüsü Dergisi, 10(3), 328-333.

[7] Çiçek, E., Birecikligil, S. 2015. Yüzeysel Sularda Su Kalitesinin Değerlendirmesi ve İzlenmesi için Biyolojik Bütünlük İndeksi: Balık İndekslerinin Kullanılması. Nevşehir Bilim ve Teknoloji Dergisi, 4(1), 45-56.

[8] Yeniyurt, C., Hemmami, M., Çağırankaya, S., Koopmanschap E. 2011. Türkiye'nin Ramsar Alanlarında Sulak Alan Yönetim Planları Değerlendirme Raporu. Doğa Derneği, Ankara, Türkiye.

[9] Semiz, G. D., Akşit, C. 2013. Water quality, surface area, evaporation and precipitation of Lake Burdur. Journal of Food, Agriculture and Environment, 11, 751-753.

[10] Hepdeniz, K. 2020. Determination of Burdur Lake's areal change in upcoming years using geographic information systems and the artificial neural network method. Arabian Journal of Geosciences, 13(21), 1-8.

[11] Yarıcı, M. A., Yağbasan, Ö. 2018. Burdur Gölleri Havzası'nın Morfolojik Özelliklerinin Belirlenmesinde Coğrafi Bilgi Sistemlerinin Kullanımı. TÜCAUM 30. Yıl Uluslararası Coğrafya Sempozyumu.

[12] Ataol, M. 2010. Burdur Gölü'nde Seviye Değişimleri. Coğrafi Bilimler Dergisi, 8(1), 77-92.

[13] Ayaz, S. Ç., Aktaş, Ö., Dağlı, S., Aydöner, C., Atasoy Aytış, E., Akça, L. 2013. Pollution loads and surface water quality in the Kızllırmak Basin, Turkey, Desalin. Desalination and Water Treatment, 51(7-9), 1533-1542.

[14] Kaya, L. G., Yücedağ, C., Duruşkan, Ö. 2015. Burdur Gölü Havzasının Çevresel Açıdan İrdelenmesi. Mehmet Akif Ersoy Üniversitesi Fen Bilimleri Enstitüsü Dergisi, 6 (1), 6-10.

[15] Özçelik, H., Çinbilgel, İ., Koca, A., Muca, B. 2014. Mermer Ocaklarının Burdur Florası Üzerine Etkileri. Ulusal Mermer ve Taş Ocakları Onarım Teknikleri Sempozyumu, 18-20.

[16] Kazanci, N., Türkmen, G., Basören, Ö., Ekingen, P. 2016. TR-BMWP (Turkish-BMWP) biotic index. Review of Hydrobiology, 9(2), 147-151.

[17] Uysal, R. A. 2011. Firat Nehri üzerindeki barajların (Keban, Karakaya, Atatürk) bölgenin yağış ve sıcaklık değerlerine etkisi. Niğde Üniversitesi, Eğitim Bilimleri Enstitüsü Yüksek Lisans Tezi, 8s, Niğde.
[18] Akın, M., Akın, G. 2007. Suyun Önemi, Türkiye'de $\mathrm{Su}$ Potansiyeli, Su Havzaları Ve Su Kirliliği. Ankara Üniversitesi Dil ve Tarih-Coğrafya Fakültesi Dergisi, 2, 105-118.

[19] Temponeras, M., Kristiansen, J., Moustaka-Gouni, M. 2000. Seasonal variation in phytoplankton composition and physical-chemical features of the shallow Lake Doïrani, Macedonia, Greece. he Trophic Spectrum Revisited, Springer, 109-122.

[20] Ayhan, Ü., Çoban, F., Tunç, M. S. 2008. Hazar Gölü $\mathrm{Su}$ Kalitesinin Fiziksel Ve İnorganikkimyasal Parametreler Açısından İncelenmesi. Gazi Üniversitesi Mühendislik Mimarlık Fakültesi Dergisi, 23(1), 119-127.

[21] Kıymaz, G. 2017. Su Kaynaklarının Kalite Modellemesi-Alaşehir Çayı Alt Havzası Akarsuları Su Kalitesi Modelleme Uygulaması. Uzmanlık Tezi, TC. Orman ve Su İşleri Bakanlığı, 145s, Ankara.

[22] Maraslioglu, F., Soylu, E. N. 2017. Relationship of epilithic diatom communities to environmental variables in Yedikır Dam Lake (Amasya, Turkey). Turkish Journal of Fisheries and Aquatic Sciences, 17(7), 1347-1356.

[23] Şehnaz, Ş., Şener, E., Davraz, A., Varol, S. 2020. Hydrogeological and hydrochemical investigation in the Burdur Saline Lake Basin, southwest Turkey. Geochemistry, 80(4), 125592.

[24] TÜBİTAK MAM, 2016. Türkiye'de Havza Bazında Hassas Alanların ve Su Kalitesi Hedeflerinin Belirlenmesi Projesi. Final Raporu, T.C. Orman ve Su İşleri Bakanlığl.

[25] Türkiye İstatistik Kurumu (TÜİK), https://biruni.tuik.gov.tr/medas/(Erişim Tarihi: 27.02.2021).

[26] TÜBİTAK MAM, 2010. Havza Koruma Eylem Planlarının Oluşturulması Projesi. T.C. Orman ve Su İşleri Bakanlığı.

[27] DSİ, 2009. Devlet Su İşleri Genel Müdürlügü, Kalite İzleme İstasyon Verileri.

[28] YSKY, 2015. Yerüstü Su Kalitesi Yönetmeliği. Resmi Gazete Sayı:29327, 1-30.

[29] SYGM, 2015. İklim Değişikliğinin Su Kaynaklarına Etkisi Projesi. Su Yönetimi Genel Müdürlüğü, T.C. Orman ve Su İşleri Bakanlığı.

[30] MGM,2019. Meteoroloji Genel Müdürlüğü, Meteoroloji İzleme Verileri.

[31] Burdur İli Çevre Durum Raporu, 2019. Burdur İl Çevre Müdürlüğü, 33-38s, Burdur.

[32] Burdur İl Gelişim Planı ve Gelişim Stratejileri, 2019. Mehmet Akif Ersoy Üniversitesi (MAKÜ) ve Batı Akdeniz Kalkınma Ajansı (BAKA), Detay Anatolia Akademik Yayıncılık. 
[33] Burdur Havzası Nehir Havzası Yönetim Planı, 2019. Stratejik Cevresel Değerlendirme Kapsam Belirleme Raporu (Taslak). Tarım ve Orman Bakanlığı, Su Yönetimi Genel Müdürlüğü.

[34] Ölgen, K. 2010. Türkiye'de Ylllık ve Mevsimsel Yağış Değişkenliğinin Alansal Dağılımı. Ege Coğrafya Dergisi, 19, 85-95.
[35] Anonim, 2015. Yer Üstü Suları, Yer Altı Suları ve Sedimentten Numune Alma Ve Biyolojik Örnekleme Tebliği. Resmî Gazete:29274, T.C. Orman ve Su İșleri Bakanlığı. 